\title{
APPROACHES TO ESTIMATING MARINE PROTEIN IN HUMAN COLLAGEN FOR RADIOCARBON DATE CALIBRATION
}

\author{
Genevieve Dewar \\ Department of Anthropology, University of Toronto, 19 Russell Street, Toronto, Ontario M5S 2S2, Canada. Corresponding \\ author. Email: gdewar@utsc.utoronto.ca. \\ Susan Pfeiffer \\ Department of Archaeology, University of Cape Town, Private Bag, Rondebosch 7701, South Africa.
}

\begin{abstract}
Determining the appropriate approach to calibrating radiocarbon dates is challenging when unknown and variable fractions of the carbon sample are derived from terrestrial and marine systems. Uncalibrated dates from a large number of human skeletons from Western Cape and Southern Cape locales, South Africa $(n=187)$, can be used to explore alternate approaches to the marine carbon correction. The approach that estimates theoretically expected minimum and maximum values for marine carbon ("expected") is compared to the approach that estimates observed minimum and maximum values ("observed"). Two case studies are explored, wherein skeletons interred together have non-overlapping conventional ${ }^{14} \mathrm{C}$ ages. The case from the Western Cape is explored through carbon isotope values; the case from the Southern Cape uses nitrogen isotope values. In both cases, the approach using observed endpoints yields better date calibration results. Analysis of the large sample shows that mean values for estimated dietary \% Marine, as calculated using expected and observed protocols, are significantly different. We conclude that the observed protocol is preferred, and that improved measures of the local marine reservoir $(\Delta \mathrm{R})$ are needed for this region.
\end{abstract}

\section{INTRODUCTION}

Archaeological studies document evidence for culture change through the identification of relative changes in the material record; the timing of these events is often quantified through radiocarbon dating. Conventional ${ }^{14} \mathrm{C}$ ages should be calibrated into calendar dates, taking into account all the relevant independent variables, including whether the dated samples were derived from either the terrestrial or marine environment, or from a mixture of these environments during life. Prior to calibration, it must be determined if there is an offset in ${ }^{14} \mathrm{C}$ age (an offset between terrestrial and marine carbon of the same actual calendar age) reflecting the marine reservoir effect. If the dated material represents a life in which both terrestrial and marine carbon supported the organism, the relative proportions must be estimated. This is the case when dates come from the bone collagen of humans who ate variable amounts of terrestrial and marine protein during their lives.

The terrestrial calibration curves IntCal09 (Reimer et al. 2009) and SHCal04 (McCormac et al. 2004) account for the variation in atmospheric production of ${ }^{14} \mathrm{C}$ in the Northern and Southern hemispheres. The Marine09 calibration curve (Reimer et al. 2009) accounts for the variation in atmospheric ${ }^{14} \mathrm{C}$ and the global marine reservoir effect $\mathrm{R}(\mathrm{t})$. The surface layer $(0-75 \mathrm{~m})$ of the world's oceans consists of both contemporary carbon and older ${ }^{14} \mathrm{C}$-depleted waters brought up from the deep ocean through upwelling. The average ${ }^{14} \mathrm{C}$ age of the world's ocean surface layers is $405 \pm 22$ $\mathrm{yr}$, a value that changes through time because of factors including the differences in atmospheric $\mathrm{CO}_{2}$, ocean depth, and circulation systems (see Stuiver et al. 1986; Stuiver and Braziunas 1993:140). In addition to $R(t)$, each region has its own deviation, or local marine reservoir effect $(\Delta R)$, based on local mixing of currents and sources of upwelling (Stuiver and Braziunas 1993). The local marine reservoir effect can add or subtract ${ }^{14} \mathrm{C}$ years from the global marine reservoir effect, ranging from $<300 \mathrm{yr}$ to $>1600 \mathrm{yr}$ in the Southern Ocean (Southon et al. 2002; Butzin et al. 2005; Fairbanks 2007). The calibration of ${ }^{14} \mathrm{C}$ dates may have a substantial impact on interpretations of the past.

Three methods have been proposed for measuring $\Delta \mathrm{R}$. The first approach is that of ${ }^{14} \mathrm{C}$ dating known-age "pre-nuclear bomb" marine shells from museum collections. The difference between the calculated date and the known age of the specimens constitutes $\Delta \mathrm{R}$. The second approach, similar to 
the first, generates $\Delta \mathrm{R}$ from paired marine and terrestrial ${ }^{14} \mathrm{C}$ dates from archaeological samples. The third approach generates $\Delta \mathrm{R}$ from the difference between onshore terrestrial and offshore marine species from tephra isochrones (Ascough et al. 2005). Research to date has assumed that $\Delta \mathrm{R}$ remains constant through time, in part because there are insufficient data available for exploration of alternate hypotheses. However, recent studies show that during deglaciation in high-latitude regions, $\Delta \mathrm{R}$ can shift by a factor of 2 (Hughen et al. 2004; Fairbanks 2007; Ascough et al. 2009). At present, $R(t)$ is accommodated within the Marine 04 curve using values obtained from low-latitude regions that are not as greatly affected by deglaciation events (Hughen et al. 2004).

While the calibration of terrestrial- and marine-based samples has been simplified through research into the accuracy and precision of the calibration curves and their regular amendment, it is still difficult to properly calibrate samples that have mixed terrestrial and marine protein components. An example is human bone from coastal contexts. Before such a sample can be correctly calibrated, the proportion of marine to terrestrial carbon in the bone collagen (\% Marine) must be accurately estimated. This relies on interpretation of data from dietary stable isotope analysis (cf. Chisholm et al. 1983; Lidén and Nelson 1994; Richards and Mellars 1998; Arneborg et al. 1999; Barrett et al. 2000; Schulting and Richards 2001). Only then can calibration software such as CALIB 5.0 (Stuiver et al. 2005) and OxCal 4.1 (Bronk Ramsey 1995, 2001, 2009) be used to generate an accurate calibration of the conventional ${ }^{14} \mathrm{C}$ date.

This study evaluates 2 proposed methods that can be used to quantify \% Marine from bone collagen samples. Both methods are based on linear calculations of the range of isotope values using endpoints to represent $0 \%$ Marine and $100 \%$ Marine contribution to diet. The approach that we will refer to as the "expected" method uses endpoints that are based on measured values from the local food chain (not human dietary values), adjusted for fractionation effects (see below). This approach was first applied by Ambrose (1993), but it can be considered to be a modified version of the Schwarcz et al. (1985) formula for estimation of $\% \mathrm{C}_{4}$. This method has been used by various researchers to determine \% Marine for purposes of calibrating ${ }^{14} \mathrm{C}$ dates obtained from human bone collagen (Lubell et al. 1994; Coltrain et al. 2004; Prowse et al. 2004; Keenleyside et al. 2006). The alternate approach, which we will refer to as the "observed" method, uses endpoints obtained directly from human skeletal tissue. It reflects only the range of values actually observed within a local region. The observed endpoints approach was first proposed and demonstrated by Chisholm et al. (1982). It, too, has been widely used for calibrating ${ }^{14} \mathrm{C}$ dates from human tissue of people with mixed diets (Chisholm et al. 1983; Lidén and Nelson 1994; Richards and Mellars 1998; Arneborg et al. 1999; Barrett et al. 2000; Schulting and Richards 2001). This paper evaluates both the expected and observed methods to determine \% Marine, in order to identify which of the 2 methods is more appropriate (accurate) in the context of coastal southern Africa.

\section{STABLE ISOTOPES}

Stable isotope ratios of carbon and/or nitrogen $\left(\delta^{13} \mathrm{C}\right.$ and $\left.\delta^{15} \mathrm{~N}\right)$ can be used to estimate the percentages of marine and terrestrial carbon in bone collagen (Tauber 1981; Schoeninger et al. 1983; Schoeninger and DeNiro 1984; Sealy and van der Merwe 1986, 1988; Sealy 2006). Bone collagen reflects the average isotopic composition of an individual's dietary protein input for a period of at least 10 yr prior to death (Ambrose 1993). Stable isotopes of carbon and nitrogen from bone collagen are measured using isotope-ratio mass spectrometry (see Sealy and Pfeiffer 2000 for a description of the method used on the skeletons in this study) and expressed as a ratio ${ }^{13} \mathrm{C} /{ }^{12} \mathrm{C}$ relative to a standard $\left(\delta^{13} \mathrm{C}\right)$, or ${ }^{15} \mathrm{~N} /{ }^{14} \mathrm{~N}$ relative to a standard $\left(\delta^{15} \mathrm{~N}\right)$. The formula for carbon is $\delta^{13} \mathrm{C}$ sample $=\left\{\left[{ }^{13} \mathrm{C} /{ }^{12} \mathrm{C}\right.\right.$ sample $\div{ }^{13} \mathrm{C} /{ }^{12} \mathrm{C}$ std $\left.]-1\right\} \times 1000$ or per mil $\left(\%\right.$ ) and for nitrogen it is $\delta^{15} \mathrm{~N}$ sample $=\left\{\left[{ }^{15} \mathrm{~N} /{ }^{14} \mathrm{~N}\right.\right.$ sam- 
ple $\div{ }^{15} \mathrm{~N} /{ }^{14} \mathrm{~N}$ std] -1$\} \times 1000$ or per mil $(\%)$. The standard for carbon is PeeDee Belemnite marine limestone (PDB). Most living organisms have less $\delta^{13} \mathrm{C}$ than PDB, which means the $\delta^{13} \mathrm{C}$ value will be negative. The value of $\delta^{15} \mathrm{~N}$ is calculated the same way as $\delta^{13} \mathrm{C}$, but most living organisms have values that are more positive than the standard of atmospheric nitrogen (AIR). Isotopic values between diet and the consumer's collagen are fractionated or enriched during metabolic synthesis (van der Merwe and Vogel 1978; Schoeninger and DeNiro 1984; Sealy et al. 1987; Bocherens and Drucker 2003; Hedges and Reynard 2007).

The preferred approach to identify marine versus terrestrial diets is to use both carbon and nitrogen isotope values in conjunction. However, certain characteristics of the local environment can be limiting (see below).

\section{CARBON ISOTOPES}

Carbon in the form of carbon dioxide $\left(\mathrm{CO}_{2}\right)$ is fixed through photosynthesis following either a $\mathrm{C}_{3}$ or $\mathrm{C}_{4}$ pathway. Trees and bushes typically fix carbon following the $\mathrm{C}_{3}$ Calvin-Benson pathway, discriminating against $\delta^{13} \mathrm{C}$, producing an average pre-industrial $\delta^{13} \mathrm{C}$ ratio of $-25.5 \%$. Most tropical grasses fix carbon following the $\mathrm{C}_{4}$ Hatch-Slack pathway, with less discrimination against $\delta^{13} \mathrm{C}$, producing an average pre-industrial $\delta^{13} \mathrm{C}$ value of $-11.5 \%$. Based on studies of large herbivores and humans, van der Merwe and Vogel (1978) suggest that there is an average shift of 5\%o between dietary intake and bone collagen (but see Bocherens and Drucker 2003 who suggest a shift of 0 to $2 \%$ between herbivores and carnivores). Using these fractionation values, pre-industrial herbivores consuming $\mathrm{C}_{3}$ plants will have a bone collagen $\delta^{13} \mathrm{C}$ value of $-21 \%$, while pre-industrial herbivores that solely ate $\mathrm{C}_{4}$ plants should have a value of $-6 \%$. As the isotope values do not overlap, they can be used to identify diet. There is also a third pathway called CAM (Crassulacean Acid Metabolism) used by desert plants such as cacti and succulents. These types of plants utilize both methods of fixing carbon and therefore can have $\delta^{13} \mathrm{C}$ values reflecting either a $\mathrm{C}_{3}$ or a $\mathrm{C}_{4}$ pathway, or intermediate between the two.

The fractionation of carbon between plants and large herbivores is typically 5\% (van der Merwe and Vogel 1978). Since the onset of the Industrial Revolution and the mass burning of fossil fuels of infinite age, the atmospheric ${ }^{14} \mathrm{C}$ signal has been diluted by $\sim 2 \%$ (Suess 1958). Isotope measurements on old shallow-water sponges record a decline in $\delta^{13} \mathrm{C}$ of $0.85 \%$ in the marine system (Böhm et al. 2002), while tree rings and ice cores reflect a shift of $1.5 \%$ to $1.6 \%$ (Friedli et al. 1986; Leavitt 1993). The carbon isotope value of marine $\mathrm{CO}_{2}$ today is $0 \%$, while atmospheric $\mathrm{CO}_{2}$ is $-8 \%$, but for most of the Holocene, the period covered in this study, these values were closer to $-1 \%$ for the marine system and $-6.5 \%$ for the terrestrial system. In this paper, when pre-industrial stable isotope values are discussed, the offsets (or Suess effect) are accounted for.

The marine ecosystem is enriched in $\delta^{13} \mathrm{C}$ compared to the terrestrial system, and with every step up the food chain, isotopic values are enriched from diet to consumer tissue through metabolic synthesis. However, current research suggests that the value of enrichment is not always clear and can vary depending on the relative amount of protein available in the diet. Experimental studies comparing high- and low-protein diets have shown that this factor can affect how collagen is synthesized (Hare et al. 1991; Ambrose and Norr 1993; Tieszen and Fagre 1993; Macko et al. 1999; Howland et al. 2003). Protein consists of 2 categories of amino acids: non-essential that the body synthesizes, and essential that must be obtained from the diet. Through study of controlled swine diets, Howland et al. (2003) showed that carbon in essential amino acids could be routed directly to synthesize collagen, with minimal fractionation. In high-protein diets, non-essential amino acids are more likely to be directly routed to collagen than those from de novo biosynthesis (Howland et al. 2003; Corr et 
al. 2005). Studies by Keenleyside et al. (2006) and Prowse et al. (2004) suggest that in low-protein diets with a marine component, the carbon in collagen is preferentially derived from carbohydrates, in this case $\mathrm{C}_{3}$ terrestrially based carbon. These factors make it difficult to accurately estimate the fractionation or enrichment shift between diet and consumer's tissue, unless the diet of the consumer is well established. This is a difficult task when the tissue is derived from past populations.

In studies of marine species from the coast of South Africa, filter-feeding shellfish (low trophic level species) have an average $\delta^{13} \mathrm{C}$ value of about $-16 \%$, while the flesh of higher trophic level seals has a $\delta^{13} \mathrm{C}$ value of about $-12 \%$ (Sealy and van der Merwe 1986; Sealy 2006). Assuming a fractionation value of $5 \%$, individuals consuming low trophic level seafood will have bone collagen values around $-11 \%$ while consumers of seal meat should have a value $\delta^{13} \mathrm{C}$ around $-7 \%$. The $\delta^{13} \mathrm{C}$ values for $\mathrm{C}_{4}$ and marine-based diets overlap, and hence can lead to confusion. However, carbon isotopes can be used to differentiate between terrestrial- and marine-based diets in regions that lack $\mathrm{C}_{4}$ plants. In such settings, enriched $\delta^{13} \mathrm{C}$ values (less negative) indicate a diet with some proportion of marine carbon, while depleted $\delta^{13} \mathrm{C}$ values (more negative) indicate diets based on terrestrial herbivores and $\mathrm{C}_{3}$ plants. When both $\mathrm{C}_{4}$ plants and marine resources are present, carbon cannot be used to distinguish between terrestrial and marine diets. While it is preferred to use both carbon and nitrogen isotopes to evaluate the proportion of marine protein in the diet, the presence of $\mathrm{C}_{4}$ plants in the local environment precludes the use of carbon isotopes. In this case, nitrogen isotopes must be used alone.

\section{NITROGEN ISOTOPES}

Atmospheric nitrogen gas $\left(\mathrm{N}_{2}\right)$ is fixed into ammonium, nitrates, and nitrites by nitrogen-fixing microorganisms. Ammonium and nitrites are taken up by plants and converted into plant proteins. Nitrogen in animal diets comes from protein, so the $\delta^{15} \mathrm{~N}$ value of a consumer's tissue reflects the protein component of the diet (Sealy 2006). Fractionation of nitrogen is typically 3-5\%o per trophic level (Schoeninger and DeNiro 1984; Sealy et al. 1987; Bocherens and Drucker 2003; Hedges and Reynard 2007), although variations in trophic level shifts among ruminants have been noted (Sponheimer et al. 2003). Based on data from archaeological sites from other parts of the world, terrestrial animals have a mean $\delta^{15} \mathrm{~N}$ of $5.9 \pm 2.2 \%$ (Schoeninger and DeNiro 1984), with herbivores averaging $4.9 \pm 1.6 \%$ and carnivores $8.0 \pm 1.6 \%$.

Marine organisms normally have $\delta^{15} \mathrm{~N}$ values that are more positive than those of terrestrial plants due to the additional trophic levels within the marine ecosystem. Thus, the $\delta^{15} \mathrm{~N}$ values of high trophic level marine animals are enriched relative to terrestrial animals. The exceptions are values from fish that inhabit shallow coral reef environments. They have less enriched nitrogen values (Keegan and DeNiro 1988) because they consume sea grasses that follow a different nitrogen fixing pathway. There are no coral reef species in this study.

At the archaeological site of Nelson Bay Cave on the Southern Cape coast of South Africa, within the study area of this research, the $\delta^{15} \mathrm{~N}$ values of mussels range from 5 to $10 \%$ while seals average $16.8 \pm 1.7 \%$ (Sealy 2006). In Mediterranean environments like the Southern Cape, $\delta^{15} \mathrm{~N}$ ratios can be used to identify marine versus terrestrial diets. The skeletal remains of people who consumed a diet with a high proportion of marine resources will show more positive $\delta^{15} \mathrm{~N}$ values than those of people who ate diets with a high proportion of terrestrial foods (Schoeninger et al. 1983; Sealy et al. 1987). In arid environments, nitrogen cannot distinguish between marine and terrestrial diets, because fauna adapted to aridity tend to have very high $\delta^{15} \mathrm{~N}$ values, similar to marine signals (Ambrose and DeNiro 1986; Sealy et al. 1987; Ambrose 1991a,b; but see Sponheimer et al. 2003 for alternative explanations of enriched $\delta^{15} \mathrm{~N}$ values). These factors have been taken into account in designing this study. 


\section{CURRENT METHODS TO DERIVE \% MARINE}

Both of the methods that have been proposed for estimating the proportion of dietary marine carbon in human skeletal remains are linear models that rely on the identification of the range of isotopic values of local foods. The expected method identifies the theoretically expected endpoint values that human bone collagen should exhibit, based on the measurements of the local flora and fauna, adding the appropriate fractionation value:

$$
\% \text { Marine }=\left(\delta_{\mathrm{T}}-\delta_{\mathrm{CO}}-\Delta_{\mathrm{CD}}\right) \div\left(\delta_{\mathrm{M}}-\delta_{\mathrm{T}}\right) \times 100
$$

where $\delta_{\mathrm{T}}$ is the average $\delta^{13} \mathrm{C}$ of terrestrial dietary sources; $\delta_{\mathrm{CO}}$ is the $\delta^{13} \mathrm{C}$ value of human collagen; $\Delta_{\mathrm{CD}}$ is the fractionation factor $\left(\delta_{\mathrm{CO}}-\delta_{\text {diet }}\right)$; and $\delta_{\mathrm{M}}$ is the average $\delta^{13} \mathrm{C}$ of marine resources (Ambrose 1993). When using nitrogen isotopes, the same formula is used.

The observed method identifies the observed endpoint values that have been measured directly from human collagen taken from skeletons within a study area:

$$
\% \text { Marine }=\left(\delta_{\mathrm{t}}-\delta_{\mathrm{CO}}\right) \div\left(\delta_{\mathrm{m}}-\delta_{\mathrm{t}}\right) \times 100
$$

where $\delta_{\mathrm{t}}$ is the most depleted $\delta^{13} \mathrm{C}$ value from the local sample, which is assumed to represent a $100 \%$ terrestrial diet; $\delta_{\mathrm{CO}}$ is the $\delta^{13} \mathrm{C}$ value of human collagen; and $\delta_{\mathrm{m}}$ is the most enriched $\delta^{13} \mathrm{C}$ value in the sample, which is assumed to represent a $100 \%$ marine-based diet. Again, $\delta^{15} \mathrm{~N}$ values can be substituted for carbon values. In previous studies (Chisholm et al. 1983; Lidén and Nelson 1994; Richards and Mellars 1998; Arneborg et al. 1999; Barrett et al. 2000; Schulting and Richards 2001 ), the $100 \%$ terrestrial endpoint value is taken from a skeleton found buried inland within the geographic region of interest, while the $100 \%$ Marine endpoint has been more difficult to identify. In many studies, the $100 \%$ Marine value has been taken from measurements from aboriginal human skeletons from coastal British Columbia, Canada (Chisholm et al. 1982), where multiple lines of evidence support an assumption that the diet was heavily dependent on salmon. This assumption may be inappropriate for studies of ecological settings that differ from that Northern Hemisphere locale. This study uses local values from South African skeletal remains.

Two case studies from South African coastal sites are used to evaluate the expected and the observed methods of estimating \% Marine. Both models are based on a linear range of values with endpoints representing a $0 \%$ Marine (100\% terrestrial) and a 100\% Marine ( $0 \%$ terrestrial) diet. The expected model requires an input for the assumed fractionation value from dietary source to consumer, while the observed method does not. While previous studies have focused on carbon isotopes, this study includes a case in which nitrogen isotopes are the more appropriate measures of dietary marine protein. The context of each case study suggests that ${ }^{14} \mathrm{C}$ dates for human skeletons buried together should be contemporaneous. It is against this assumption that results will be assessed. The method of determining \% Marine that returns calibrated dates that are the most similar will be deemed to be the most accurate method, based on assumptions of parsimony.

Because the case study approach does not provide much information on the broader impact of applying either of the 2 methods, a brief exploration is also made into the effect of wholesale application of either method. Dates are calibrated for each of the Later Stone Age adult skeletons with published dates and isotope values, from both the Western and Southern capes, and the results for each method are assessed. 


\section{MATERIALS AND METHODS}

\section{Case Studies}

The first case study focuses on 2 juveniles found buried together at the Modder River Mouth, Western Cape, South Africa (catalog designations SAM-AP 6054A and SAM-AP 6054B) (Figure 1). Their estimated ages at death are 13 and $6 \mathrm{yr}$ of age, respectively. They are assumed to be well beyond the age of weaning. These individuals were photographically documented when they were discovered, buried back to back in a shelly sand dune (Pfeiffer and van der Merwe 2004), yet the conventional ${ }^{14} \mathrm{C}$ ages of $2530 \pm 60 \mathrm{BP}(\mathrm{Pta}-4151)$ and $2780 \pm 45 \mathrm{BP}$ (Pta-4211) do not overlap, suggesting that their deaths could not have been contemporaneous (Table 1 and Figure 2). This case illustrates the application of expected and observed methods in the context of carbon isotopes. The Western Cape is a region with very little $\mathrm{C}_{4}$ component to the flora (Sealy and van der Merwe 1986, 1988), so carbon isotopes can be used to identify the \% Marine in the diet from each individual.

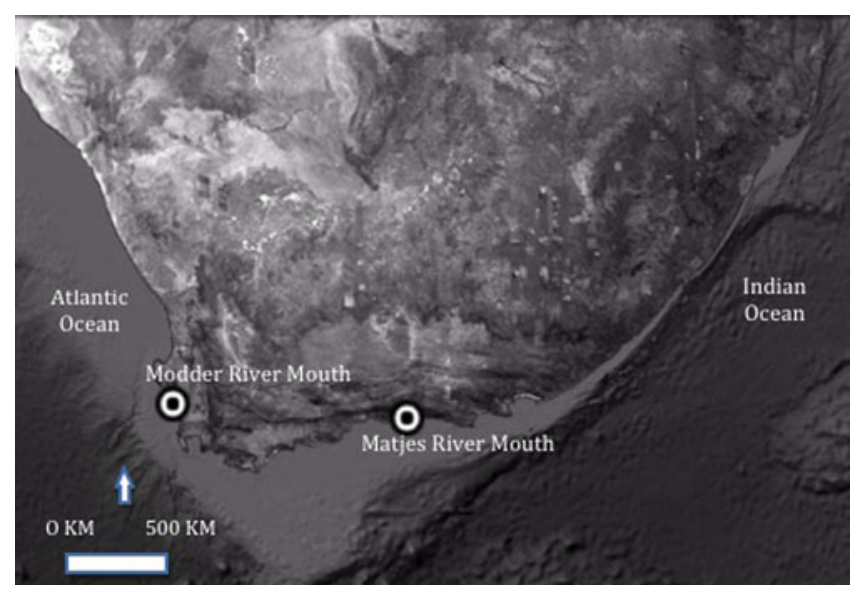

Figure 1 Map of South Africa with dots identifying the locations of the sample sites Modder River Mouth, Western Cape, and Matjes River Rock Shelter, Southern Cape.

The second case study focuses on 2 adults from the Matjes River Rock Shelter, Southern Cape, South Africa (Figure 1). They are curated at the National Museum Bloemfontein (NMB in the figures), under the designation "Unmarked Matjes River (Grave No 1, SS II to IV)"). The Matjes River Rock Shelter held a very deep midden deposit that was excavated in the late 1920s and again in the 1950s (Louw 1960; Dockel 1998; Sealy et al. 2006). The materials of interest were held by the museum, uncataloged, as they were brought back from the field. While their simultaneous interment cannot be assured, their removal as a single unit makes it probable. In 1999, it was observed by Pfeiffer and Sealy that there were in fact 2 adults within in the same box. While documentation is less than ideal, the comingled skeletons of interest appear to have been the product of a mid-1950s excavation by museum staff. Their individuation was undertaken by Pfeiffer and Sealy, based on age at death, skeletal size, and shape characteristics. The adult skeletons, designated A (male) and B (female), were then ${ }^{14} \mathrm{C}$ dated. The conventional ${ }^{14} \mathrm{C}$ ages have ranges that do not overlap, at $5148 \pm$ 33 BP (OxA-11940) and $5368 \pm 35$ BP (OxA-11941) (Figure 2 and Table 1). The Southern Cape region has a $\mathrm{C}_{4}$ component, preventing the use of carbon isotopes to calculate \% Marine. However, conditions in the Southern Cape make it appropriate to use nitrogen isotopes to identify \% Marine. 

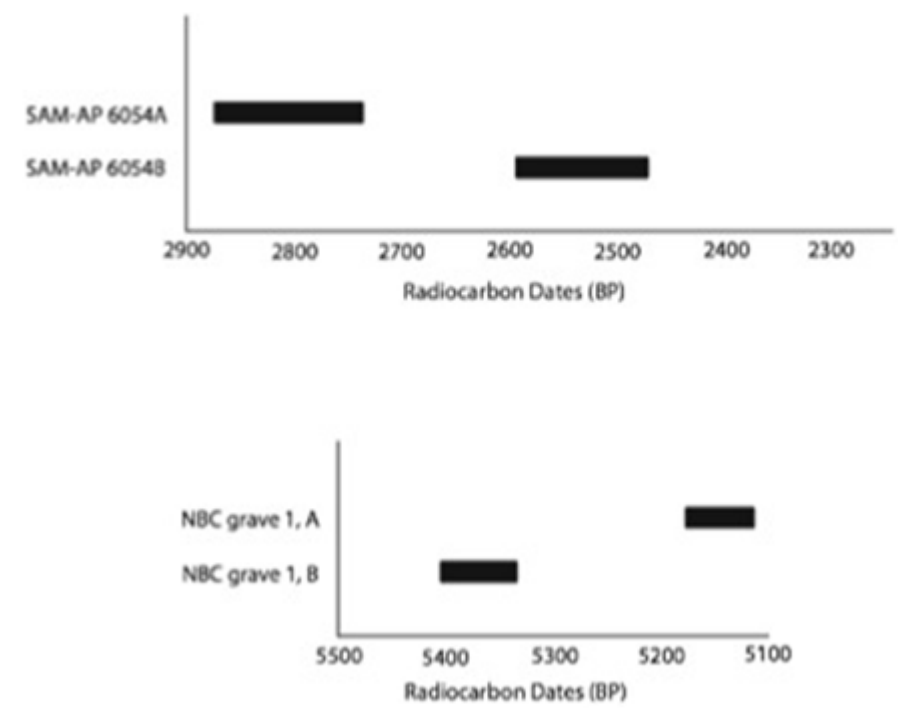

Figure 2 Conventional ${ }^{14} \mathrm{C}$ ages of the Modder River children (above) and the Matjes River Adults (below).

Table $1{ }^{14} \mathrm{C}$ dates and stable isotope analyses for the Modder River Mouth and Matjes River Grave 1 individuals, from bone collagen. The ${ }^{14} \mathrm{C}$ dates of the Modder River individuals were analyzed at the CSIR lab in Pretoria, South Africa, while the dates from the Matjes River Grave 1 individuals were analyzed at the OxCal lab in Oxford, England. The Archaeometry Laboratory at the University of Cape Town conducted the isotope analyses.

\begin{tabular}{llllll}
\hline Skeleton & $\begin{array}{l}{ }^{14} \mathrm{C} \text { date } \\
(\mathrm{BP})\end{array}$ & Lab nr & $\begin{array}{l}\delta^{13} \mathrm{C} \\
(\%)\end{array}$ & $\begin{array}{l}\delta^{15} \mathrm{~N} \\
(\%)\end{array}$ & $\begin{array}{l}\text { UCT Archaeometry } \\
\text { Lab \# }\end{array}$ \\
\hline SAM6054A & $2780 \pm 45$ & Pta-4211 & -11.7 & 15.6 & 1731 \\
SAM6054B & $2530 \pm 60$ & Pta-4151 & -14.8 & 14.8 & 1732 \\
Grave 1, A & $5148 \pm 33$ & OxA-11940 & -12.8 & 13.8 & 7415 \\
Grave 1, B & $5368 \pm 35$ & OxA-11941 & -11.8 & 15.9 & 7416 \\
\hline
\end{tabular}

\section{The Skeletal Series}

The determination of the expected and observed endpoint values for $\%$ Marine draws on published dietary isotope values from a large sample of adult skeletons from the Western and Southern Cape regions (Sealy and van der Merwe 1988; Sealy and Pfeiffer 2000; Pfeiffer and Sealy 2006) $(n=187)$. The sample includes 90 skeletons from the Western Cape and 97 from the Southern Cape. The carbon and nitrogen isotope values from both regions reflect diverse dietary choices that include low and high \% Marine. Previous research using these dietary values and the uncalibrated dates has postulated dietary and behavioral change through time and space, within the Later Stone Age (cf. Pfeiffer and Sealy 2006).

For skeletons from the Western Cape, carbon isotopes were used to calculate expected and observed $\%$ Marine. For skeletons from the Southern Cape, nitrogen isotopes were used for those calculations. When characterizing a diet as $100 \%$ Marine, this refers only to the protein component, and is acknowledged to be an approximation. A diet comprised solely of marine protein is nutritionally impossible, but it is not clear what the maximum proportion of dietary intake that can be derived from marine sources is, so the $100 \%$ value is applied here. 


\section{Calculation of Expected Endpoints}

The expected endpoints were derived from measures of flora and fauna samples from the coastal and near-coastal regions of South Africa. For carbon, $\mathrm{C}_{3}$ plants average $-27 \%$ while the highest trophic level carnivorous marine mammal, the Cape fur seal (Arctocephalus pusillus), averages $-12.8 \%$ (Sealy and van der Merwe 1988; Sealy 2006). Accounting for the Suess effect shift of $1.5 \%$ and adding 5\% for the fractionation expected between diet and consumer, bone collagen from a prehistoric vegan who ate a $100 \%$ terrestrial diet should have an expected $\delta^{13} \mathrm{C}$ value of $-20.5 \%$, while bone collagen from someone who ate a diet with all of its protein coming from high level marine sources $(100 \%$ Marine) should have a value of $-7.8 \%$. There is a range of $12.7 \%$ o between endpoints, so each positive $1 \%$ is assumed to reflect an increase of marine protein in the diet by $7.8 \%$. Using nitrogen isotopes, terrestrial herbivores have an average $\delta^{15} \mathrm{~N}$ value of $4.7 \pm 1.0 \%$ (Sealy 2006), while marine carnivores such as the Cape fur seal have an average $\delta^{15} \mathrm{~N}$ value of $16.8 \pm 1.7 \%$ (Muller 2002). In this region, bone collagen from a human vegan with $100 \%$ terrestrial diet would have a nitrogen isotope value of $4.7 \%$, the same as the terrestrial herbivore, while a human consumer of a $100 \%$ Marine diet would have an isotopic value of $20.8 \%$, after adding $4 \%$ for fractionation. There is a range of $16.1 \%$ between endpoints, so for purposes of calculation, each positive $1 \%$ is assumed to reflect an increase of marine protein in the diet by $6.2 \%$.

\section{Calculation of Observed Endpoints}

Published values for Western Cape human skeletons (Sealy and van der Merwe 1986; Pfeiffer and Sealy 2006 ) indicate a range in carbon values from $-10.6 \%$ to $-19 \%$. The heavier values were measured in 2 skeletons (AM-AP 4203A and SAM-AP 5075) that were recovered from coastal locales (Kommetjie and Cape Point). The lighter values were measured in 2 skeletons (UCT 333 and UCT 334) that were recovered from the inland region of Clanwilliam. The former value is presumed to reflect something close to $100 \%$ of protein coming from a marine source, and thus forms the upper observed endpoint. The latter value is presumed to reflect a $100 \%$ terrestrial diet where negligible protein is coming from a marine source. This produces a range of $8.4 \%$ between endpoints; thus, each addition of $1 \%$ reflects an increase of marine protein in the diet by $11.9 \%$. Nitrogen isotope values for Southern Cape human skeletons (Pfeiffer and Sealy 2006; J Sealy, personal communication) show endpoint values of 18.3\% (SAM-AP 5052) from a burial from the Robberg Peninsula, and $8 \%$ (ALB 282) from a burial from Plettenberg Bay. (Although that locale is coastal, a recent age for this individual suggests that the person may have been a pastoralist.) The former value is presumed to reflect something close to $100 \%$ Marine, and the latter reflects a $100 \%$ terrestrial diet. This produces a range of $10.3 \%$ between endpoints; thus, each addition of $1 \%$ reflects an increase of marine protein in the diet by $9.7 \%$.

\section{Calibration of Dates}

${ }^{14} \mathrm{C}$ dates were calibrated using OxCal 4.1 using the Mix_Curves option that mixes the SHCal04 (McCormac et al. 2004) and Marine09 (Reimer et al. 2009) calibration curves using the proposed value of $\%$ Marine and $\Delta \mathrm{R}$ (Bronk Ramsey 1995, 2001, 2009). The SHCal04 curve accounts for a 40 -yr difference in atmospheric absorption of $\mathrm{CO}_{2}$ between the Southern and Northern hemispheres. The local marine reservoir effect value $(\Delta \mathrm{R})$ for the Western Cape is $224 \pm 51 \mathrm{yr}$ and for the Eastern Cape it is $213 \pm 57 \mathrm{yr}$ (Southon et al. 2002). Because there is no measured $\Delta \mathrm{R}$ for the Southern Cape, the weighted average of the $\Delta \mathrm{R}$ values from the Western and Eastern capes was used. This value is $219 \pm 38$ yr (Marine Reservoir Correction Database, http://calib.qub.ac.uk/marine/). While the expected and observed methods each identify a specific \% Marine value, an estimate of the error 
associated with that value must be included in the calibration exercise. In this study, the value of $10 \%$ is used, following Schulting and Richards (2001).

\section{RESULTS AND DISCUSSION}

\section{Case Studies}

When expected carbon isotope endpoints are used to estimate \% Marine values of the 2 juveniles from Modder River Mouth, the estimated \% Marine protein in the diet is $66 \pm 10 \%$ for SAM 6054A and $44 \pm 10 \%$ Marine for SAM 6054B (Table 2). When those values are used to calibrate the ${ }^{14} \mathrm{C}$ dates, the ranges of their dates still do not overlap (Figure 3). When observed carbon isotope endpoints are used as the basis for \% Marine estimates, the estimated \% Marine in the diet is $87 \pm 10 \%$ for SAM $6054 \mathrm{~A}$ and $50 \pm 10 \%$ for SAM $6054 \mathrm{~B}$ (Table 2). The ranges of the resulting calibrated dates overlap substantially (Figure 4). Assuming co-interment, the observed endpoint method yields superior results.

Table 2 Carbon isotopes were used to determine \% Marine for Modder River Mouth, Western Cape individuals using the expected and observed endpoints and a $\Delta \mathrm{R}$ of $224 \pm 51 \mathrm{yr}$.

\begin{tabular}{lllll}
\hline & Endpoints: & \% Marine & Calibrated & Calibrated \\
& 100\% Terrestrial to & SAM6054A & date (BP) & date BP \\
& 100\% Marine & SAM6054B & $1 \sigma$ & $2 \sigma$ \\
\hline Expected endpoints & $-20.4 \%$ to $-7.8 \%$ & $66 \%$ & $2602-2335$ & $2689-2312$ \\
& & $44 \%$ & $2340-2159$ & $2466-2050$ \\
Observed endpoints & $-19.0 \%$ to $-10.6 \% 0$ & $86.9 \%$ & $2393-2193$ & $2323-2149$ \\
& & $50 \%$ & $2496-2132$ & $2421-1996$ \\
\hline
\end{tabular}
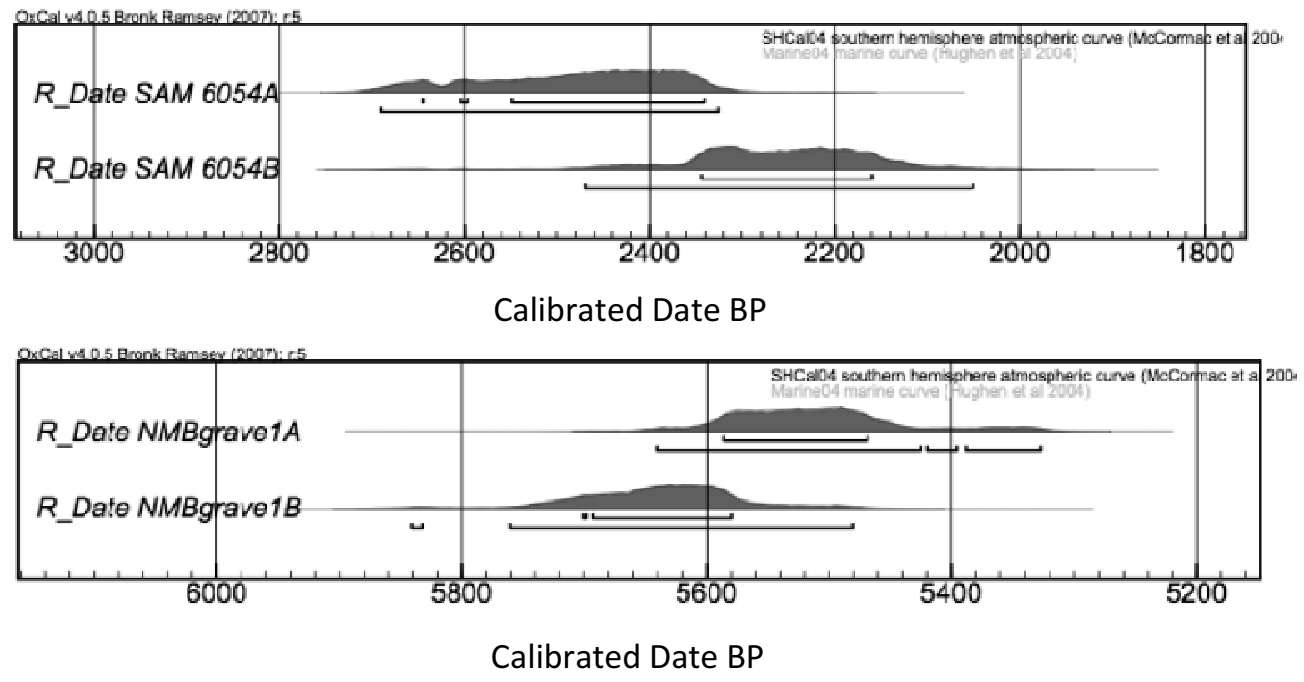

Figure 3 Expected \% Marine values used to calibrate ${ }^{14} \mathrm{C}$ dates for both Modder River (SAM 6054) and Matjes River (Grave 1) samples.

When expected nitrogen isotope endpoints are used to estimate the \% Marine for the diet of the 2 adults from the Matjes River Rock Shelter, the \% Marine in the diet of Grave 1A is $56 \pm 10 \%$ and Grave 1B is $70 \pm 10 \%$ (Table 3). When those values are used to calibrate the ${ }^{14} \mathrm{C}$ dates, the ranges 


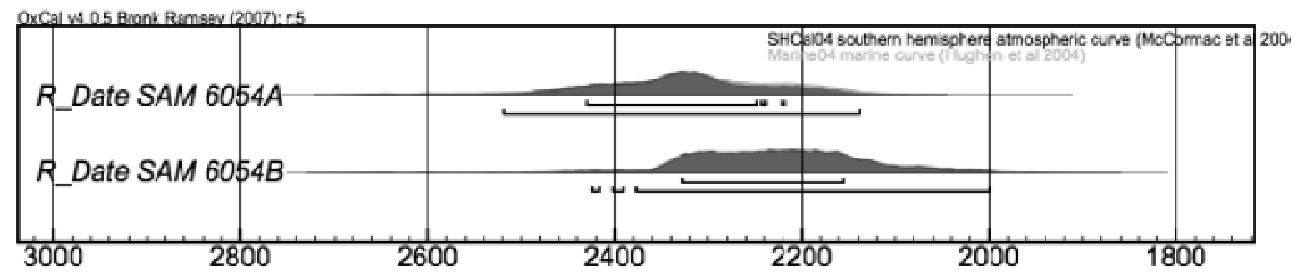

Calibrated Date BP

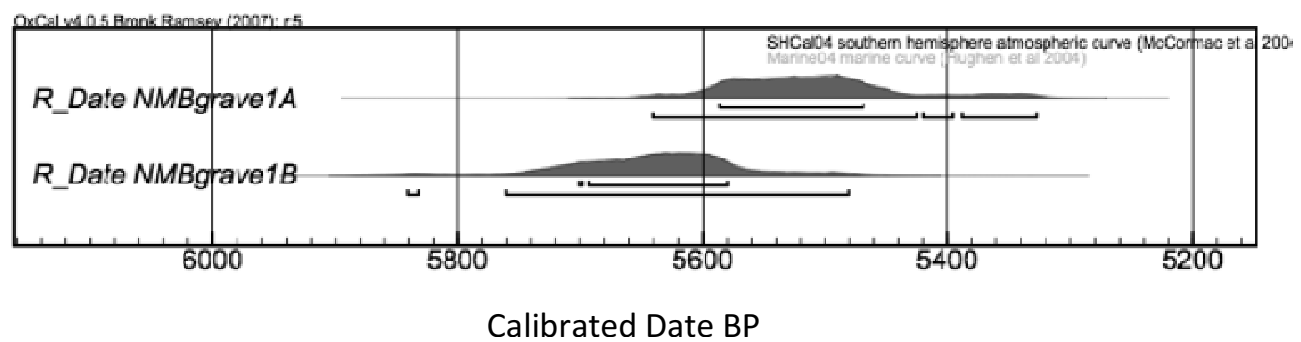

Figure 4 Observed \% Marine values used to calibrate ${ }^{14} \mathrm{C}$ dates for both Modder River (SAM 6054) and Matjes River (Grave 1) samples.

of the dates are brought nearer, but the ranges still do not overlap (Figure 3). When observed nitrogen endpoints are used as the basis of \% Marine estimates, the \% Marine in the diet of the Grave $1 \mathrm{~A}$ is $59 \pm 10 \%$ and that of Grave $1 \mathrm{~B}$ is $80 \pm 10 \%$ (Table 3 ). The resulting calibration generates dates that are similar to the calibration based on the previously described "expected" method (Figure 4).

Table 3 Nitrogen isotopes were used to determine \% Marine for Grave $1 \mathrm{~A}$ and B, Southern Cape, using the expected and observed endpoints and a $\Delta \mathrm{R}$ of $219 \pm 38 \mathrm{yr}$.

\begin{tabular}{lllll}
\hline & $\begin{array}{l}\text { Endpoints: } \\
\text { 100\% Terrestrial to }\end{array}$ & $\begin{array}{l}\text { \% Marine } \\
\text { Grave 1, A }\end{array}$ & $\begin{array}{l}\text { Calibrated } \\
\text { date (BP) }\end{array}$ & $\begin{array}{l}\text { Calibrated } \\
\text { date (BP) }\end{array}$ \\
& $100 \%$ Marine & Grave 1, B & $1 \sigma$ & $2 \sigma$ \\
\hline Expected endpoints & $4.7 \%$ to $20.8 \%$ o & $56.4 \%$ & $5591-5472$ & $5650-5329$ \\
& & $69.4 \%$ & $5730-5600$ & $5866-5571$ \\
Observed endpoints & $8 \%$ to $18.3 \%$ & $58.6 \%$ & $5587-5460$ & $5697-5574$ \\
& & $79.8 \%$ & $5613-5325$ & $5756-5471$ \\
\hline
\end{tabular}

Results from the calibrations of the ${ }^{14} \mathrm{C}$ dates using both expected and observed \% Marine values show that the method using the observed range of dietary values yields the narrowest range between dates. This is the case regardless of whether carbon or nitrogen values are used for the calculations (Tables 2 and 3). Graphs for each case study show the conventional ${ }^{14} \mathrm{C}$ ages and the 2 sets of calibrated dates derived from the expected and observed endpoints (Figures 2-4). They demonstrate that the results from the observed endpoint calculations produce the best agreement in calibrated dates. When graphed, the calibrated ${ }^{14} \mathrm{C}$ dates from the Western Cape Modder River Mouth sample overlap well when the observed endpoint values are used. The Southern Cape Matjes River Rock Shelter individuals show less overlap. 


\section{The Skeletal Series}

In order to explore the magnitude of the 2 methods' relative effects on calibration of ${ }^{14} \mathrm{C}$ dates, the $\%$ Marine value was calculated using both the expected and observed methods for each of the adult skeletons from the Western and Southern Capes. To gauge the relative magnitude of these adjustments, the overall results were compared using a $t$ test. The \% Marine values for skeletons from the Western Cape were calculated from carbon isotopes, while the \% Marine value for skeletons from the Southern Cape were calculated from nitrogen isotopes. For the Western Cape sample $(n=90)$, the mean value of \% Marine Expected is $50.5 \pm 13.1 \%$ and the mean value of \% Marine Observed is $60.7 \pm 22.1 \%$. This is a significant difference $(t=10.9, d f=89, p=0.00)$. For the Southern Cape sample $(n=97)$, the mean of the \% Marine Expected is $54.5 \pm 14.8 \%$ and the mean of the \% Marine Observed is $49.8 \pm 23 \%$. This, too, is a statistically significant difference $(t=2.93, d f=96, p=$ 0.002), although the magnitude of the difference between the 2 methods when applied to this set of values is substantially less. This exercise suggests that there may be substantial bias introduced by the estimation method that is applied. The 2 estimates of dietary marine protein that were generated through scrutiny of carbon isotope values differ by about $10 \%$. The 2 estimates of dietary marine protein that were generated from nitrogen isotope values differ by about $5 \%$. It is not clear that there is any methodological reason why the carbon isotope system should yield more disparate results than the nitrogen isotope system. This observation warrants further study.

\section{CONCLUSIONS}

The 2 methods of estimating the proportion of marine protein in the diet are based on different assumptions. The method using the expected endpoints relies on knowing the magnitude of fractionation that is occurring between trophic levels in the local ecosystem. Using the observed endpoints avoids those assumptions, since the endpoint values are taken directly from measured human bone collagen. Thus, in situations where a single skeleton from a relatively unstudied environment is of interest, the observed method may be the only plausible approach. This study sets aside this matter, and assesses efficacy of each method on the basis of whether the resulting calibrations of dates "fit" the archaeological context.

In both of the case studies, the use of regionally observed endpoints in the carbon and the nitrogen isotopic systems yields the most plausible calibrated ${ }^{14} \mathrm{C}$ dates. In the Southern Cape example in which values must be based on nitrogen isotopes, results from the 2 approaches differ only slightly. However, in the Western Cape sample, where carbon isotopes form the basis of the estimates, there is considerably more overlap using the observed method. Comparison of the outputs from the application of both expected and observed methods for calculating \% Marine has shown that using the observed isotope values from the skeletons produces dates that are more plausible than the dates based on theoretically expected isotope values. This is based on the assumption that the method used to determine \% Marine that shows most overlap of calibrated ${ }^{14} \mathrm{C}$ dates of co-interred skeletons is the most accurate. The avoidance of assumptions about metabolic pathways may be one of the factors making the observed method more accurate. Nevertheless, it must be acknowledged that the observed method probably underestimates the intake of marine protein at the $0 \%$ end, and overestimates the intake of marine protein at the $100 \%$ end. Neither method is without its weaknesses.

A possible explanation for the lack of complete overlap of the dates for the 2 skeletons from Matjes River Rock Shelter is that the local marine reservoir value is not accurate. The $\Delta \mathrm{R}$ values for South Africa are based on single "pre-bomb" dated shells, one from AD 1945 (Western Cape) and the other from AD 1820 (Eastern Cape). This is a very sparse database upon which to construct a framework of dates. Research has shown that $\Delta \mathrm{R}$ values can change through time (Ingram 1998), and 
marine geography suggests that coasts of South Africa may have variable effects generated by different dominant currents. Along the east coast, the warm Agulhas Current dominates, while the colder Benguela Current, with upwelling cells from the depths of the South Atlantic, affects the west coast. The south coast experiences a mixture of the two. Thus, we might expect a broader range of values for $\Delta \mathrm{R}$, with older average values for the Western Cape. The possibility that the available local marine offset value might be inaccurate is demonstrated when a value of $350 \mathrm{yr}$ is substituted for the prior values of $\Delta \mathrm{R}$ in $\mathrm{OxCal}$ 4.1. This $\Delta \mathrm{R}$ value (350 yr) and \% Marine values from the observed method yielded calibrated ${ }^{14} \mathrm{C}$ dates for both the case studies with excellent agreement (Figure 5). New dates for known-age, pre-bomb shells from various coastal locales is now underway, to establish better values for the local $\Delta \mathrm{R}$ for southern Africa. Another possible explanation for our results is that the 2 skeletons in the case study died and were buried at different times. As other candidates for comparison are identified from carefully controlled, modern excavations, this topic can be investigated further.

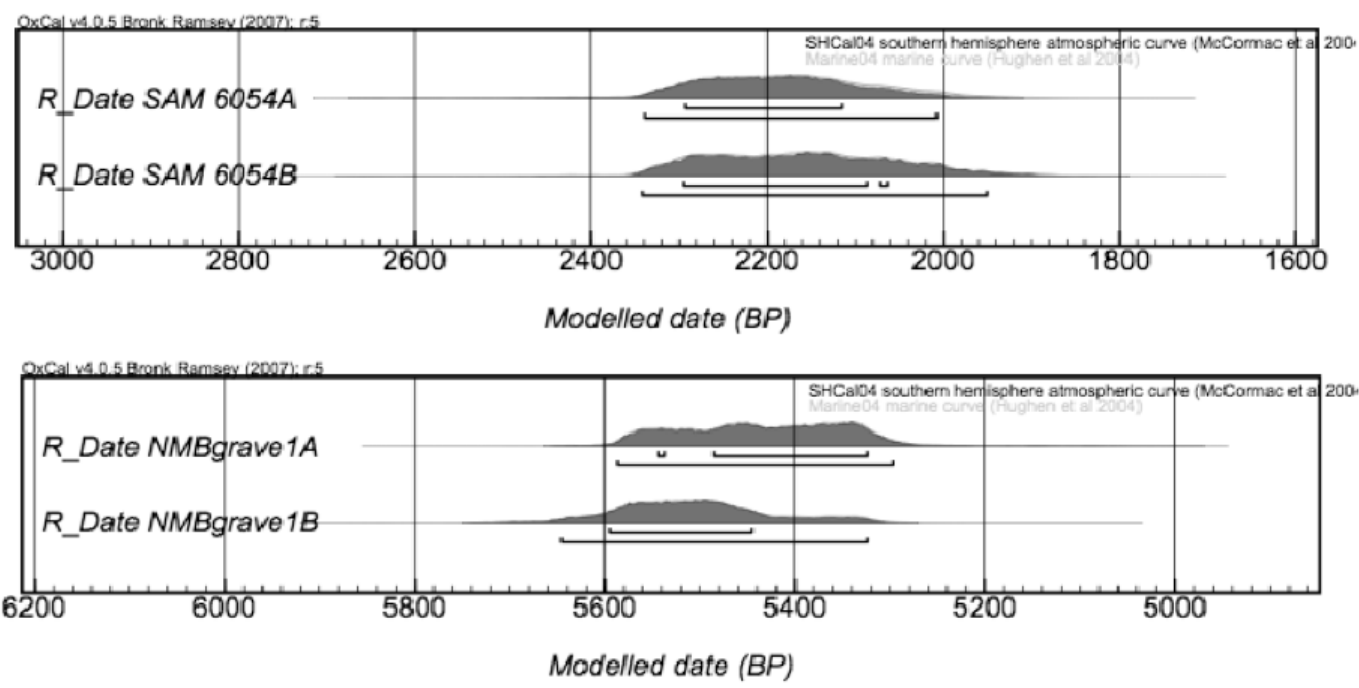

Figure 5 Observed \% Marine values were used to calibrate the conventional ${ }^{14} \mathrm{C}$ dates for both Modder River (SAM 6054) and Matjes River (NMB Grave 1) samples, based on a $\Delta \mathrm{R}$ of $350 \mathrm{yr}$.

The application of the 2 approaches for estimating \% Marine on a large sample of adult skeletons from South African locales illustrates that the choice of method can have a substantial impact on archaeological interpretations. Each of the methods provides calibrated dates that are more plausible than the original dates, but we argue that the observed method is preferable. This research has provided some benchmarks regarding the magnitude of error that different approaches may generate. While there continue to be challenges, we suggest that leaving the dates uncalibrated should not be considered an option. It is important that researchers attend to the demonstrated impact of marine carbon on ${ }^{14} \mathrm{C}$ dates, and that they apply calibration approaches that are appropriate to the ecology of the geographic region that they seek to understand. This study contributes to the important and growing body of research on the calibration of ${ }^{14} \mathrm{C}$ dates from coastal contexts, especially those that are based on collagen from human skeletal remains. The dietary decisions of these innovative, adaptable omnivores provide significant challenges to our attempts to reconstruct their behavior. The methodological issues addressed here need further study and resolution if we are to accurately determine the timing of past behavioral changes in these dynamic environments. 


\section{ACKNOWLEDGMENTS}

The authors acknowledge the substantial body of excellent research by J C Sealy and N J van der Merwe, upon which this research builds. Their comments were helpful to us during this research. The research was supported by a grant to SP from the Social Sciences and Humanities Research Council of Canada.

\section{REFERENCES}

Ambrose SH. 1991a. Effects of diet, climate and physiology on nitrogen isotope abundances in terrestrial foodwebs. Journal of Archaeological Science 18(3): 293-17.

Ambrose SH. 1991b. Stable isotopic analysis of human diet in the Marianas Archipelago, western Pacific. American Journal of Physical Anthropology 104(3): 343-61.

Ambrose SH. 1993. Isotope analysis of palaeodiets: methodological and interpretative considerations. In: Sandford MK, editor. Investigations of Ancient Human Tissue: Chemical Analyses in Anthropology. Reading: Gordon and Breach Science Publishers. p 59-129.

Ambrose SH, DeNiro MJ. 1986. The isotopic ecology of East African mammals. Oecologia 69(3):395-406.

Ambrose SH, Norr L, editors. 1993. Isotopic composition of dietary protein and energy versus bone collagen and apatite: purified diet growth experiments. In: Lambert JB, Grupe G, editors. Molecular Archaeology of Prehistoric Human Bone. Berlin: Springer. p 1-37.

Arneborg J, Heinemeier J, Lynnerup N, Nielsen H, Rud N, Sveinbjörnsdóttir Á. 1999. Change of diet of the Greenland Vikings determined from stable carbon isotope analysis and ${ }^{14} \mathrm{C}$ dating of their bones. Radiocarbon 41(2):157-68.

Ascough P, Cook G, Dugmore A. 2005. Methodological approaches to determining the marine radiocarbon reservoir effect. Progress in Physical Geography 29(4):532-47.

Ascough P, Bird M, Brock F, Higham T, Meredith W, Snape CE, Vane CH. 2009. Hydropyrolysis as a new tool for radiocarbon pre-treatment and the quantification of black carbon. Quaternary Geochronology 4(2): 140-7.

Barrett J, Beukens R, Brothwell D. 2000. Radiocarbon dating and marine reservoir correction of Viking Age Christian burials form Orkney. Antiquity 74(285): $537-43$.

Bocherens H, Drucker D. 2003. Trophic level isotopic enrichment of carbon and nitrogen in bone collagen: case studies from recent and ancient terrestrial ecosystems. International Journal of Osteoarchaeology 13(1-2):46-53.

Böhm F, Haase-Schramm A, Eisenhauer A, Dullo WC, Joachimski MM, Lehnert H, Reitner J. 2002. Evidence for preindustrial variations in the marine surface water carbonate system from coralline sponges. Geochemistry Geophysics Geosystems 3(3):1019, doi: 10.1029/2001GC000264.

Bronk Ramsey C. 1995. Radiocarbon calibration and analysis of stratigraphy: the OxCal program. Radiocarbon 37(2):425-30.

Bronk Ramsey C. 2001. Development of the radiocarbon calibration program. Radiocarbon 43(2A):355-63.

Bronk Ramsey C. 2009. Bayesian analysis of radiocarbon dates. Radiocarbon 51(1):337-60.

Butzin M, Prange M, Lohmann G. 2005. Radiocarbon simulations for the glacial ocean: the effects of wind stress, Southern Ocean sea ice and Heinrich events. Earth and Planetary Science Letters 235(1-2):45-61.

Chisholm B, Nelson DE, Schwarcz HP. 1982. Stable-carbon isotope ratios as a measure of marine versus terrestrial protein in ancient diets. Science 216(4550): 1131-2.

Chisholm B, Nelson DE, Schwarcz HP. 1983. Marine and terrestrial protein in prehistoric diets on the British Columbia coast. Current Anthropology 24(3):396-8.

Coltrain JB, Hayes MG, O'Rourke D. 2004. Sealing, whaling and caribou: the skeletal isotope chemistry of Eastern Arctic foragers. Journal of Archaeological Science 31(1):39-57.

Corr LT, Sealy JC, Horton MC, Evershed RP. 2005. A novel marine dietary indicator utilising compoundspecific bone collagen amino acid $\delta^{13} \mathrm{C}$ values of ancient humans. Journal of Archaeological Science 32(3):321-30.

Dockel W. 1998. Re-investigation of the Matjes River Rock Shelter. Stellenbosch: University of Stellenbosch. p 1-87.

Fairbanks RG. 2007. Radiocarbon reservoir age [WWW document]. URL: http://www.radiocarbon.ldeo.columbia.edu/research/resage.htm.

Friedli H, Löstscher H, Oeschger H, Sieganthaler U, Stauffer B. 1986. Ice core record of the ${ }^{13} \mathrm{C} /{ }^{12} \mathrm{C}$ ratio of atmospheric $\mathrm{CO}_{2}$ in the past two centuries. Nature 324(6094): 237-8.

Hare PE, Fogel ML, Stafford TW, Mitchell AD, Hoering TC. 1991. The isotopic composition of carbon and nitrogen in individual amino acids isolated from modern and fossil proteins. Journal of Archaeological Science 18(3):277-92.

Hedges R, Reynard L. 2007. Nitrogen isotopes and the trophic level of humans in archaeology. Journal of Archaeological Science 34(8):1240-51. 
Howland MR, Corr L, Young SMM, Jones V, Jim S. 2003. Expression of the dietary isotope signal in the compound-specific $\delta^{13} \mathrm{C}$ values of pig bone lipids and amino acids. International Journal of Osteoarchaeology 13(1):54-65.

Hughen KA, Baillie MGL, Bard E, Beck JW, Bertrand CJH, Blackwell PG, Buck CE, Burr GS, Cutler KB, Damon PE, Edwards RL, Fairbanks RG, Friedrich M, Guilderson TP, Kromer B, McCormac G, Manning S, Ramsey CB, Reimer PJ, Reimer RW, Remmele S, Southon JR, Stuiver M, Talamo S, Taylor FW, van der Plicht J, Weyhenmeyer CE. 2004. Marine04 marine radiocarbon age calibration, 0-26 cal kyr BP. Radiocarbon 46(3):1059-86.

Ingram LB. 1998. Differences in radiocarbon age between shell and charcoal from a Holocene shellmound in northern California. Quaternary Research 49(1): $102-10$.

Keegan W, DeNiro M. 1988. Stable carbon and nitrogen ratios of bone collagen used to study coral-reef and terrestrial components of prehistoric Bahamian diet. American Antiquity 53(2):320-36.

Keenleyside A, Schwarcz H, Panayotova K. 2006. Stable isotopic evidence of diet in a Greek colonial population from the Black Sea. Journal of Archaeological Science 33(9):1205-15.

Leavitt S. 1993. Environmental information from ${ }^{13} \mathrm{C} /$ ${ }^{12} \mathrm{C}$ ratios of wood. Geophysical Monograph 78:32531.

Lidén K, Nelson DE. 1994. Stable carbon isotopes as dietary indicators in the Baltic area. Fornvännen 89:1321.

Louw J. 1960. Prehistory of the Matjes River Rock Shelter. Bloemfontein: National Museum of Bloemfontein Memoir.

Lubell D, Jackes M, Schwarcz H, Knyf M, Meiklejohn C. 1994. The Mesolithic-Neolithic transition in Portugal: Isotopic and dental evidence of diet. Journal of $\mathrm{Ar}$ chaeological Science 21(2):201-16.

Macko S, Engel M, Andrusevich V, Lubec G, O’Connell T, Hedges R. 1999. Documenting the diet in ancient human populations through stable isotope analysis of hair. Philosophical Transactions: Biological Sciences 354(1379):65-76.

McCormac FG, Hogg AG, Blackwell PG, Buck CE, Higham TFG, Reimer PJ. 2004. SHCal04 Southern Hemisphere calibration, 0-11.0 cal kyr BP. Radiocarbon 46(3): 1087-92.

Muller C. 2002. Investigation of possible dietary differences between the inhabitants of the Robberg/Plettenberg Bay and Matjes River Rock Shelter in the Later Stone Age: an isotopic approach [MA thesis]. Cape Town: University of Cape Town.

Pfeiffer S, Sealy J. 2006. Body size among Holocene foragers of the Cape ecozone, southern Africa. American Journal of Physical Anthropology 129(1):1-11.

Pfeiffer S, van der Merwe NJ. 2004. Cranial injuries to
Later Stone Age children from the Modder River Mouth, Southwestern Cape, South Africa. South African Archaeological Bulletin 59(180):59-65.

Prowse T, Schwarcz HP, Saunders S, Macchiarelli R, Bondioli L. 2004. Isotopic paleodiet studies of skeletons from the Imperial Roman-age cemetery of Isola Sacra, Rome, Italy. Journal of Archaeological Science 31(3):259-72.

Reimer PJ, Baillie MGL, Bard E, Bayliss A, Beck JW, Blackwell PG, Bronk Ramsey C, Buck CE, Burr GS, Edwards RL, Friedrich M, Grootes PM, Guilderson TP, Hajdas I, Heaton TJ, Hogg AG, Hughen KA, Kaiser KF, Kromer B, McCormac FG, Manning SW, Reimer RW, Richards DA, Southon JR, Talamo S, Turney CSM, van der Plicht J, Weyhenmeyer CE. 2009. IntCal09 and Marine09 radiocarbon age calibration curves, $0-50,000$ years cal BP. Radiocarbon 51(4): 1111-50.

Richards MP, Mellars PA. 1998. Stable isotopes and the seasonality of the Oronsay middens. Antiquity 72(275): 178-84.

Schoeninger MJ, DeNiro MJ. 1984. Nitrogen and carbon isotopic composition of bone collagen from marine and terrestrial animals. Geochemica et Cosmochimica Acta 48(4):625-39.

Schoeninger MJ, DeNiro MJ, Tauber H. 1983. Stable nitrogen isotope ratios of bone collagen reflect marine and terrestrial components of prehistoric human diet. Science 220(4604):1381-3.

Schulting RJ, Richards MP. 2001. Dating women and becoming farmers: new palaeodietary and AMS dating evidence from the Breton Mesolithic cemeteries of Teviec and Hoedic. Journal of Anthropological Archaeology 20(3):314-44.

Schwarcz HP, Melbye J, Katzenberg MA, Knyf M. 1985. Stable isotopes in human skeletons of southern Ontario: reconstructing palaeodiet. Journal of Archaeological Science 12(3):187-206.

Sealy J. 2006. Diet, mobility and settlement pattern among Holocene hunter-gatherers in southernmost Africa. Current Anthropology 47(4):569-95.

Sealy J, Pfeiffer S. 2000. Diet, body size and landscape use among Holocene peoples in the Southern Cape, South Africa. Current Anthropology 41(4):642-55.

Sealy JC, van der Merwe NJ. 1986. Isotope assessment and the seasonal-mobility hypothesis in the southwestern Cape of South Africa. Current Anthropology 27(2):135-50.

Sealy JC, van der Merwe NJ. 1988. Social, spatial and chronological patterning in marine food use as determined by $\delta^{13} \mathrm{C}$ measurements of Holocene human skeletons from the south-western Cape, South Africa. World Archaeology 20(1):87-102.

Sealy JC, van der Merwe NJ, Lee Thorp JA, Lanham JL. 1987. Nitrogen isotopic ecology in southern Africa: implications for environmental and dietary tracing. Geochemica et Cosmochimica Acta 51(10):2707-17. 
Sealy J, Ludwig B, Henderson Z. 2006. New radiocarbon dates for Matjes River Rock Shelter. South African Archaeological Bulletin 61(183):98-101.

Southon JR, Kashgarian M, Fontugne M, Metivier B, Yim WW-S. 2002. Marine reservoir corrections for the Indian Ocean and southeast Asia. Radiocarbon 44(1):167-80.

Sponheimer M, Robinson T, Ayliffe L, Roeder B, Hammer J, Passey B, West A, Cerling T, Dearing D, Ehleringer J. 2003. Nitrogen isotopes in mammalian herbivores: hair $\delta^{15} \mathrm{~N}$ values from a controlled feeding study. International Journal of Osteoarchaeology 13: 80-7.

Stuiver M, Braziunas TF. 1993. Modeling atmospheric ${ }^{14} \mathrm{C}$ influences and ${ }^{14} \mathrm{C}$ ages of marine samples to 10,000 BC. Radiocarbon 35(1):137-89.

Stuiver M, Pearson GW, Braziunas TF. 1986. Radiocar- bon age calibration of marine samples back to 9000 cal yr BP. Radiocarbon 28(2B):980-1020.

Stuiver M, Reimer PJ, Reimer RW. 2005. CALIB 5.0. [WWW program and documentation]. URL: http:// calib.qub.ac.uk/calib/.

Suess H. 1958. The radioactivity of the atmosphere and hydrosphere. Annual Review of Nuclear Science 8: $243-56$.

Tauber H. $1981 .{ }^{13} \mathrm{C}$ evidence for dietary habits of prehistoric man in Denmark. Nature 292(5821):332-3.

Tieszen L, Fagre T. 1993. Carbon isotopic variability in modern and archaeological maize. Journal of Archaeological Science 20(1):25-40.

van der Merwe NJ, Vogel JC. $1978 .{ }^{13} \mathrm{C}$ content of human collagen as a measure of prehistoric diet in woodland North America. Nature 276(5690):815-6. 